\title{
Kebermaknaan Hidup Perempuan Korban KDRT: Konsep Psikologis dan Faktor yang Melatarbelakanginya
}

\author{
Maysitoh $^{1}$, Dini Fitriani ${ }^{2}$ \\ Jurusan Bimbingan dan Konseling, Universitas Negeri Padang, Sumatera Barat \\ Indonesia, may@konselor.org, dinifitrianiii15@gmail.com
}

\begin{abstract}
Rumah tangga seharusnya menjadi tempat berlindung bagi seluruh anggota keluarga. Realita yang terjadi di masyarakat telah banyak rumah tangga yang justru menjadi tempat pennyiksaan dan kekerasan. Berbagai kondisi tidak menyenangkan dialami oleh perempuan sebagai korban. Hal itu tentunya mempengaruhi kondisi psikologis korban, terlebih lagi jika kekerasan tersebut terjadi secara berkelanjutan. Namun, tidak sedikit korban yang mengalami tindak kekerasan memutuskan untuk tetap bertahan dalam kehidupan pernikahan. Padahal mereka tahu bahwa mereka akan tetap terluka. Kebermaknaan hidup merupakan keadaan dimana orang tersebut merasa bahagia dan bebas dari kecemasan. Kajian ini menggunakan metode kepustakaan (library research), sedangkan pengumpulan data dilakukan dengan menelaah dan/atau mengekplorasi beberapa jurnal, buku, hasil penelitian, dan dokumen-dokumen (baik yang berbentuk cetak maupun elektronik) serta sumber-sumber data dan atau informasi lainnya yang dianggap relevan dengan kajian. Tujuan kajian ini yaitu menyajikan konsep psikologis dan faktor yang melatarbelakangi perempuan korban KDRT memaknai hidupnya.
\end{abstract}

Keywords: Makna hidup, Korban KDRT, konsep psikologis, faktor yang melatarbelakangi.

Article History: Received on 29X/09/2017; Revised on 07/10/2017; Accepted on 07/11/2019; Published Online: 26/11/2019.

This is an open access article distributed under the Creative Commons Attribution License, which permits unrestricted
use, distribution, and reproduction in any medium, provided the original work is properly cited. (C)2019 by author.

\section{PENDAHULUAN}

Tindak kekerasan dalam masyarakat sebenarnya bukan satu hal yang baru. Tindak kekerasan dapat menimpa siapa saja, baik laki- laki maupun perempuan, dari anak-anak sampai dewasa. Kekerasan yang marak terjadi dan menyita perhatian publik adalah kekerasan yang menimpa kaum perempuan. Terutama kekerasan yang terjadi dalam lingkup rumah tangga (Nurhidayah \& Hidayanti, 2009). Pada pasal 1 UU Nomor 23 tahun 2004 telah dijelaskan mengenai kekerasan dalam rumah tangga yaitu semua perbuatan yang dilakukan oleh seseorang yang menimbulkan kesengsaraan ataupun penderitaan secara fisik, seksual, psikologis, dan/atau penelantaran rumah tangga termasuk didlamnya ancaman untuk melakukan perbuatan, pemaksaan, atau perampasan kemerdekaan yang melawan hukum dalam lingkup rumah tangga.

Kekerasan seringkali terjadi karena adanya kesenjangan antara peran laki- laki dan perempuan dalam keluarga yang dipengaruhi oleh masih melekatnya budaya patriarki 
dalam suatu kelompok masyarakat (Mufidah, 2003). Berbagai kondisi tidak menyenangkan dialami oleh perempuan sebagai korban. Hal itu tentunya mempengaruhi kondisi psikologis korban, terlebih lagi jika kekerasan tersebut terjadi secara berkelanjutan. Perubahan kondisi psikologis tersebut bisa dilihat dari tingkah laku korban yang menjadi murung, lebih suka menyendiri merenungi nasib, tidak percaya akan adanya perubahan yang lebih baik dimasa mendatang bahkan merasa tidak memiliki semangat untuk menjalani kehidupan (Heisee, 2003). Keadaan seperti ini menyebabkan korban berpikir bahwa hidup yang dijalani sekarang ataupun dikemudian hari seakan tidak memiliki makna lagi. Penderitaan korban tidak berhenti sampai pada adanya tekanan saja selama mendapat tindak kekerasan

Ketidakmampuan manusia dalam mencapai makna dalam hidupnya akan menimbulkan dampak psikologis yang negatif. Di antara dampak tersebut adalah sulit merasakan kebahagiaan, merasa hidupnya hampa dan kosong, depresi hingga menuju tindakan bunuh diri. Ketidakberhasilan menemukan dan memenuhi makna hidup akan menimbulkan penghayatan hidup tanpa makna (meaningless), hampa, gersang, merasa tak memiliki tujuan hidup, merasa hidupnya tak berarti, bosan dan apatis (Bastaman, 2000)

Kebermaknaan hidup atau makna hidup merupakan keadaan dimana orang tersebut merasa bahagia dan bebas dari kecemasan hal ini ditandai dengan adanya target atau tujuan hidup yang memotifasi kehidupan itu sendiri, biasanya hidup yang bermakna dicapai setelah seseorang menggalami penderitaan dan pengorbanan (Mahpur, 2010). Makna hidup setiap individu akan berbeda antara satu dengan yang lainnya, karena setiap individu mempunyai pandangan yang berbeda dalam memaknai kehidupannya (Baumeister, Vohs, Aaker, \& Garbinsky, 2013). Oleh karena itulah yang terpenting dari sebuah makna bukanlah makna secara umum akan tetapi khusus individu pada satu waktu dan tempat tertentu.

\section{PEMBAHASAN}

\section{Kekerasan dalam rumah tangga}

Kekerasan merupakan sebuah terminologi yang sarat dengan arti dan makna "derita", baik dikaji dari perspektif psikologi maupun hukum, bahwa di dalamnya terkandung perilaku manusia (seseorang/kelompok orang) yang dapat menimbulkan penderitaan bagi orang lain (pribadi/ kelompok). kekerasan merupakan tindakan peneyrangan dan pelanggaran berua penyiksaan, pemukulan, pemerkosaan, dan lain-lain yang menyebabkan atau dimaksudkan orang yang dituju menderita atau menyerang orang lain hingga batas tertentu dapat dianggap sebagai kekerasan, tergantung pada situasi dan nilai-nilai sosial yang terkait dengan kekejaman terhadap binatang maupun terhadap manusia (Johny, 2011).

Peluang terjadinya tindak kekerasan dalam rumah tangga terhadap setiap individu sama, artinya KDRT bisa dialami oleh setiap orang tanpa memperdulikan latar belakang ras, jenis atau kelompok sosial dan ekonomi tertentu. Pada era sekarang ini hak-hak asasi perempuan telah mencapai tingkat yang paling signifikan dan sangat tinggi di era modern termasuk di Indonesia. Gender based violence atau kekerasan berbasis gender adalah istilah yang merujuk kepada kekerasan yang melibatkan laki-laki dan perempuan, 
biasanya yang menjadi korban adalah perempuan, sebagai akibat adanya distribusi kekuasaan yang timpang antara laki-laki dan perempuan.(Diana R, 2012).

Kekerasan terhadap perempuan dalam rumah tangga merupakan kekerasan yang berbasis gender. Hal ini karena kekerasan yang terjadi karena keyakinan gender, yang mendudukan kaum perempuan lebih rendah dibandingkan lakilaki. Kekerasan berbasis gender merupakan perwujudan ketimpangan historis dari pola hubungan kekuasaan antara laki-laki dan perempuan yang mengakibatkan dominasi dan diskriminasi terhadap perempuan oleh kaum laki-laki dan hambatan kemajuan bagi mereka (Fanslow \& Robinson, 2010). Pernyataan tersebut sangat jelas memperlihatkan adanya ketimpangan gender yang telah melembaga dalam ruang-ruang kehidupan masyarakat melalui penempatan posisi laki-laki sebagai pemegang otoritas dalam segala relasi antar manusia baik dalam ruang publik maupun domestik (Harnoko, 2010).

Pengaruh kekerasan dalam rumah tangga berakibat sangat buruk dan merusak korbannya sebagaimana pusat penelitian komunikasi dan informasi perempuan (1999), menjelaskan bahwa akibat perlakuan kejam, korban kekerasan dalam rumah tangga (KDRT) kebanyakan bercirikan antara lain (Sukeri \& Man, 2017), 1) Menderita ketegangan atau stress tingkat tinggi, 2) Menderita kecemasan, depresi dan sakit kejiwaan tingkat tinggi, 3) Berkemungkinan untuk bunuh diri, 4) Resiko keguguran dua kali lebih tinggi dibandingkan yang bukan korban kekerasan, 5) Kemampuan menghadapi dan menyelesaikan masalah lebih rendah, 6) Lebih terpencil secara social, 7) Lebih berkemungkinan bertindak kejam terhadap anak, 8) Lebih sensitif atau mudah terserang penyakit karena stress.

\section{Konsep Makna Hidup}

Istilah makna hidup dikemukakan oleh Victor Frankl, seorang dokter ahli penyaki saraf dan jiwa yang landasan teorinya disebut logoterapi. Kata logoterapi berasal dari kata "logos" yang artinya makna (meaning) atau rohani (spiritualy), sedangkan "terapi" adalah penyembuhan atau pengobatan. Logoterapi secara umum mengakui adanya dimensi kerohanian pada manusia disamping dimensi ragawi dan kejiwaan, serta beranggapan bahwa makna hidup (the meaning of life) dan hasrat untuk hidup bermakna (the will to meaning) merupakan motivasi utama manusia guna meraih taraf kehidupan bermakna (the meaningfull life) yang didambakan (Bastaman, 2000). Pencarian akan makna hidup akan berlangsung setua manusia itu sendiri. Hal ini adalah karakteristik utama yang membedakan keberadaan manusia dengan hewan (Hamdani, 2014).

Makna hidup adalah hal-hal yang dipandang penting, dirasakan berharga dan diyakini sebagai sesuatu yang benar sarta dapat dijadikan tujuan hidupnya. Makna hidup bila berhasil ditemukan dan dipenuhi akan menyebabkan kehidupan ini berarti dan biasanya individu yang menemukan dan mengembangkannya akan terhindar dari keputusasaan (Bastaman, 2000). Makna hidup dapat ditemukan dalam kehidupan itu sendiri, baik dalam keadaan yang menyenangkan dan tidak menyenangkan, keadaan bahagia, dan penderitaan. Ungkapan seperti "makna dalam derita" (meaning in suffering) atau "hikmah dalam musibah" (blessing in disguise) menunjukkan bahwa dalam penderitaan sekalipun makna hidup akan tetap dapat ditemukan. Bila hasrat ini dapat dipenuhi maka kehidupan akan dirasakan berguna, berharga dan berarti (meaningfull) akan dialami. Sebaliknya bila hasrat ini tidak terpenuhi akan menyebabkan kehidupan dirasakan tidak bermakna (meaningless), hampa dan tidak berguna .(Bastaman, 2000)

Makna hidup merupakan bagian dari kenyataan hidup yang dapat dijumpai di dalam setiap kehidupan. Oleh karena itu, makna hidup dapat berubah-ubah sewaktu- 
waktu. Makna hidup tidak dapat diberikan oleh siapapun, tetapi hanya dapat dipenuhi jika dicari dan ditemukan oleh diri sendiri (Frankl, 1984). Individu dalam mencapai makna hidupnya harus menunjukkan tindakan dari komitmen yang muncul dalam dirinya. Melalui komitmen tersebut seseorang akan menjawab tantangan yang ada dan memberikan sesuatu kepada hidup individu yang mencarinya (Mardiyati, 2015).

Makna hidup sebagaimana dikonsepkan oleh Frankl (Bastaman, 2000) memiliki beberapa karakteristik :1) Makna hidup memiliki sifat yang unik, pribadi dan temporer. Artinya segala sesuatu yang dianggap berarti oleh seseorang belum tentu berarti bagi orang lain. Dalam hal ini makna hidup seseorang dan apa yang bermakna bagi dirinya biasanya bersifat khusus, berbeda dan tidak sama dengan makna hidup orang lain. Selain itu, makna hidup tidak dapat diberikan oleh siapapun melainkan harus ditemukan sendiri (Frankl, dalam Bastaman1996). 2) Makna hidup itu spesifik dan nyata, makna hidup dapat ditemukan dalam pengalaman dan kehidupan sehari-hari serta tidak selalu dikaitkan dengan hal- hal yang abstrak, tujuan-tujuan idealistis dan prestasiprestasiakademis. 3) Makna hidup memberi pedoman dan arah tujuan terhadap kegiatankegiatan yang dilakukan.

\section{Harapan Sebagai Makna Hidup}

Menurut Bastaman, selain tiga ragam nilai yang dikemukakan Victor Frankl, ada nilai lain yang dapat menjadikan hidup ini menjadi bermakna, yaitu harapan (hope). Harapan adalah keyakinan akan terjadinya hal- hal yang baik atau perubahan yang menguntungkan dikemudian hari. Harapan sekalipun belum tentu menjadi kenyataan memberikan sebuah peluang dan solusi serta tujuan baru yang menjanjikan yang dapat menimbulkan semangat dan optimisme. Berbeda dengan orang tak memiliki harapan yang senantiasa dilanda kecemasan, keputusasaan dan apatisme, orang yang berpengharapan selalu menunjukkan sikap positif terhadap masa depan, penuh percaya diri, dan merasa optimis dapat meraih kehidupan yang lebih baik (Bastaman, 2000).

Pengharapan mengandung makna hidup karena adanya keyakinanakan terjadinya perubahan yang lebih baik, ketabahan menghadapi saat buruk ssat ini dan sikap optimis menyongsong masa depan. Harapan mungkin sekedar impian, tetapi tak jarang impian itu menjadi kenyataan. Nilai kehidupan ini dinamakan nilai pengharapan (hope) (Hamdani, 2014).

\section{Proses Pencapaian Makna Hidup}

Ada beberapa tahap penemuan makna hidup, yang terdiri dari lima kategori yakni sebagai berikut : a) Tahap derita (peristiwa tragis, penghayatan tanpa makna) Dalam tahap ini, individu berada dalam kondisi hidup yang tidak bermakna.Bisa jadi ada peristiwa tragis atau kondisi yang tidak menyenangkan. b) ahap penerimaan diri (pemahaman diri, pengubahan sikap) Pada kondisi ini muncul kesadaran diri untuk menjadi lebih baik. Kesadaran ini biasanya muncul diakibatkan perenungan, hasil dari konsultasi, mendapat pandangan dari orang lain, hasil do'a dan ibadah, belajar dari pengalaman orang lain atau peristiwa- peristiwa tertentu yang secara dramatis selama kehidupannya. c) Tahap penemuan makna hidup (penemuan makna dan penentuan makna hidup) Individu sadar akan hal- hal yang sangat penting dalam kehidupannya yang kemudian diterapkan sebagai tujuan hidup. Hal- hal penting tersebut bisa berupa nilai- nilai kreatif seperti berkarya, nilai- nilai penghayatan seperti keindahan, keimanan, keyakinan dan nilai- nilai serta sikap yang tepat dalam menghadapi kondisi yang tidak menyenangkan (Bastaman, 2000). 


\section{KESIMPULAN}

Dalam mencapai makna hidup apabila timbul dampak psikologis yang negatif ini merupakan indikasi bahwa individu gagal dalam mencapai makna hidup. Di antara dampak tersebut adalah sulit merasakan kebahagiaan, merasa hidupnya hampa dan kosong, depresi hingga menuju tindakan bunuh diri. Kegagalan individu dalam menghayati hidupnya sehingga ia merasa bahwa hidupnya tidak lagi berarti (meaningless), hampa, gersang, merasa tak memiliki tujuan hidup, bosan dan tidak mau berpartisipasi di lingkungan. Dalam hal ini perempuan korban KDRT dapat memaknai hidupnya secara positif ataupun negatif bergantung pada sumber-sumber yang melatarbelakangi makna hidupnya yaitu: 1)nilai-nilai kreatif, 2)nilai-nilai penghayatan, dan 3) nilai-nilai bersikap.

\section{REFERENCES}

Bastaman, H. . (2000). Meraih Hidup Bermakna, Kisah Pribadi dengan Pengalaman Tragis, 14-15.

Baumeister, R. F., Vohs, K. D., Aaker, J. L., \& Garbinsky, E. N. (2013). Some key differences between a happy life and a meaningful life. Journal of Positive Psychology, 8(6), 505-516. https://doi.org/10.1080/17439760.2013.830764

Diana R, P. (2012). Tindakan Kekerasan Terhadap Perempuan Dalam Keluarga. Jakarta: Program Studi Kajian Wanita Program Pasca Sarjana Universitas Indonesia.

Fanslow, J. L., \& Robinson, E. M. (2010). Help-seeking behaviors and reasons for help seeking reported by a representative sample of women victims of intimate partner violence in New Zealand. Journal of Interpersonal Violence, 25(5), 929-951.

Frankl, V. . (1984). Man Search for Meaning, an Introduction to logoterapy. (Simon \& Schuster, Eds.). New York: A Touchstone Book.

Hamdani, R. (2014). Kebermaknaan hidup pada korban tindak kekerasan dalam rumah tangga: Studi kasus life history pada korban KDRT di Bareng Bence. Universitas Islan Negeri Maulana Malik Ibrahim.

Harnoko, B. R. (2010). Dibalik tindak kekerasan terhadap perempuan. Muwazah Vol 2 No, $1,35-45$.

Heisee, L. . (2003). Violence Against Women: An Integrated, Ecological Framework, 1415.

Johny, R. H. (2011). TINDAK PIDANA KEKERASAN TERHADAP PEREMPUAN (Studi Etiologi Kriminal di Wilayah Hukum Polres Banyumas). Jurnal Dinamika Hukum, 11(2), 214-229.

Mahpur, M. (2010). Kebermaknaan Hidup pada Korban Tindak Kekerasan dalam Rumah Tangga, 2010.

Mardiyati, I. (2015). Dampak Trauma Kekerasan Dalam Rumah Tangga Terhadap Perkembangan Psikis Anak. Raheema, 2(1).

Mufidah. (2003). Paradigma Gender, 127-129.

Nurhidayah, S., \& Hidayanti, N. (2009). Hubungan Antara Ketabahan Dan Locus of Control External Dengan Kebermaknaan Hidup Pada Istri Yang Bekerja Di Bagian Sewing Pada Pt. Bosaeng Jaya Bantar Gebang Bekasi. Jurnal Soul, 2(2), 62-89 
Sukeri, S., \& Man, N. N. N. (2017). Escaping domestic violence: A qualitative study of women who left their abusive husbands. Journal of Taibah University Medical Sciences, 12(6), 477-482. 